Koltunovych Oleksandr,

PhD in economics, State Institution "Institute for Environmental Economics and Sustainable Development of the National Academy of Sciences of Ukraine"

\title{
PRIORITY DIRECTIONS OF INNOVATION AND TECHNOLOGICALM ODERNIZATION OF CERTAIN SECTORS OF THE UKRAINIAN ECONOMY
}

In the article the economic preconditions activation of innovation and technological modernization of certain sectors of the Ukrainian economy. Mechanisms of activation of the processes of modernization and innovation development, taking into account sectoral characteristics and state of the economy as a whole. Proposed priority areas for innovation and technological modernization of certain sectors of the Ukrainian economy.

Based on the identified priority areas of modernization and innovation development of economy proposed a number of priority actions to financial and tax incentives and enhance the process of developing and implementing innovative projects.

The result of the proposed mechanisms to enhance the process of innovation and technological modernization of certain sectors of Ukraine will increase the number of innovative small and medium enterprises and local developments, implemented in industry, including engineering, instrumentation, aerospace.

Keywords: innovation and technological upgrading; institutional support; clustering.

\section{REFERENCES}

1. Bakunov O. O., Roshka M. S. (2012), Bulletin of the International Nobel Economic Forum, № 1 (5), Vol. 2, pp. $19-25$ (ukr).

2. Wozniak H. V., Kuznetsova A. Ya. (2007), Innovative activity of industrial enterprises and ways of financing in Ukraine, UBS NBU Publisher, Kyiv, 183 p. (ukr).

3. Yepifanova I. Y. (2012), Analysis of the financial support of innovation of domestic enterprises in modern conditions, Bulletin of the National University "Lviv Polytechnic", № 722, pp. 65-69 (ukr).

4. Kolodizev A. N. (2011), Financial support of innovative development of the national economy, Thesis for the degree of doctor of economic sciences in specialty 08.00.08 "Money, finance and credit", Sumy, 508 p. (ukr).

5. The Water Framework Directive (Directive 2000 / 60 / EC of the European Parliament and of the Council of 23 October 2000 establishing a framework for Community action in the field of water policy), available at: http://faolex.fao.org/docs/pdf/eur23005.pdf.

(C) Колтунович Олександр

Надійшла до редакції 22.06.2015

УдК 352.07:338.24

МЕЛЬНИКОВА МАРИНА,

доктор економічних наук, дочент,

провідний науковий співробітник відділу економіко-правових проблем містознавства

Інституту економіко-правових досліджень НАН Украӥни

\section{УПРАВЛІННЯ РЕСУРСАМИ МІСЬКИХ АГЛОМЕРАЦІЙ: ПРИНЦИПИ, МЕТОДИ ТА ІНСТРУМЕНТИ}

\begin{abstract}
У статті розглянуто проблеми управління ресурсами в процесі розвитку міських агломерацій. Визначено особливості міської агломерації, серед яких необхідність об'сднання зусиль територіальних громад, що входять до складу агломерації, на основі управління їхніми ресурсами. Виявлено характерні риси ресурсів, включаючи властивості, можливості задоволення потреб, принципи, умови, способи й вартість залучення. Представлено методи та інструменти управління ресурсами міської агломерації. Запропоновано принципи, методи, інструменти управління ресурсами включати до інформаційної системи підтримки прийняття рішень $з$ управління міською агломерацією.
\end{abstract}

Ключові слова: міська агломерація; ресурси; управління; методи та інструменти управління ресурсами.

Постановка проблеми. Міські агломерації посідають важливе місце в структурі національної економіки України. Цими високоурбанізованими утвореннями, що охоплюють лише 10 \% території України, виробляється близько трьох чвертей ВВП, у них проживає дві третини населення, зосереджена значна частина основних ви- 
робничих фрондів, залучається багато інвестицій, включаючи іноземні [1]. Під міською агломерацією прийнято розуміти складну багатокомпонентну динамічну систему, яка поєднує компактно розташовану на певній території групу поселень за рахунок встановлення й розвитку тісних економічних і культурних зв'язків. Управління цією системою передбачає використання принципово нових форм методів та інструментів територіального планування й розвитку, що пов'язано з необхідністю співпраці між органами місцевого самоврядування територіальних громад, які входять до агломерації, щодо задоволення загальних потреб та інтересів. Предметами співпраці між громадами виступають розвиток транспортної та комунікаційної інфрраструктури, створення загальних логістичних центрів, координація використання міських земель, охорона навколишнього середовища, формування єдиного соціокультурного простору всередині агломерації. Указані напрями співпраці в рамках міської агломерації потребують розробки та використання відповідного ресурсного забезпечення, яке включає безпосередньо ресурси, а також принципи, методи й інструменти управління ними.

Аналіз основних досліджень. Вивченню проблем управління розвитком міських агломерацій та ресурсному забезпеченню цього процесу присвячено дослідження вітчизняних та зарубіжних учених та практиків, зокрема [1-9]. Ними розглянуто питання визначення характерних рис та еволюції міських агломерацій, особливості управління соціально-економічним розвитком, оцінено потенціал та визначено чинники розвитку міської агломерації. Проте питання управління ресурсами міської агломерації з урахуванням їхніх особливостей на підставі використання відповідних методів й інструментів вимагають детальнішого дослідження.

Метою статті $\epsilon$ визначення особливостей управління ресурсами міської агломерації на основі використання відповідних методів та інструментів.

Виклад основного матеріалу. Під ресурсами прийнято розуміти комплекс матеріальних і нематеріальних засобів, джерел, можливостей функціонування й розвитку суб'єкта економіки [10]. Управління ресурсами включає їх залучення та використання для виконання визначених цілей суб'єктом економіки шляхом обґрунтованого й збалансованого розподілу між основними напрямами й функціями діяльності для отримання доходів, що перевищують витрати на ресурси.

Особливості ресурсів як об'єкта управління полягають у такому:

- ресурси мають такі властивості, як мобільність, взаємозамінюваність (альтернативність використання), комбінованість, комплексність;

- потреби в ресурсах безмежні в уявленні, але завжди обмежені в реальності;

- залучення окремих видів ресурсів відбувається на відповідних ринках, що передбачає конкурентну боротьбу за залучення ресурсів;

- вартість ресурсів визначається цінами на ресурси або вартістю того, від чого доводиться відмовитися, щоб їх придбати.

Залучення та використання ресурсів суб'єктом економіки здійснюється відповідно до принципів, умов та способів, що узагальнено на рис. 1.

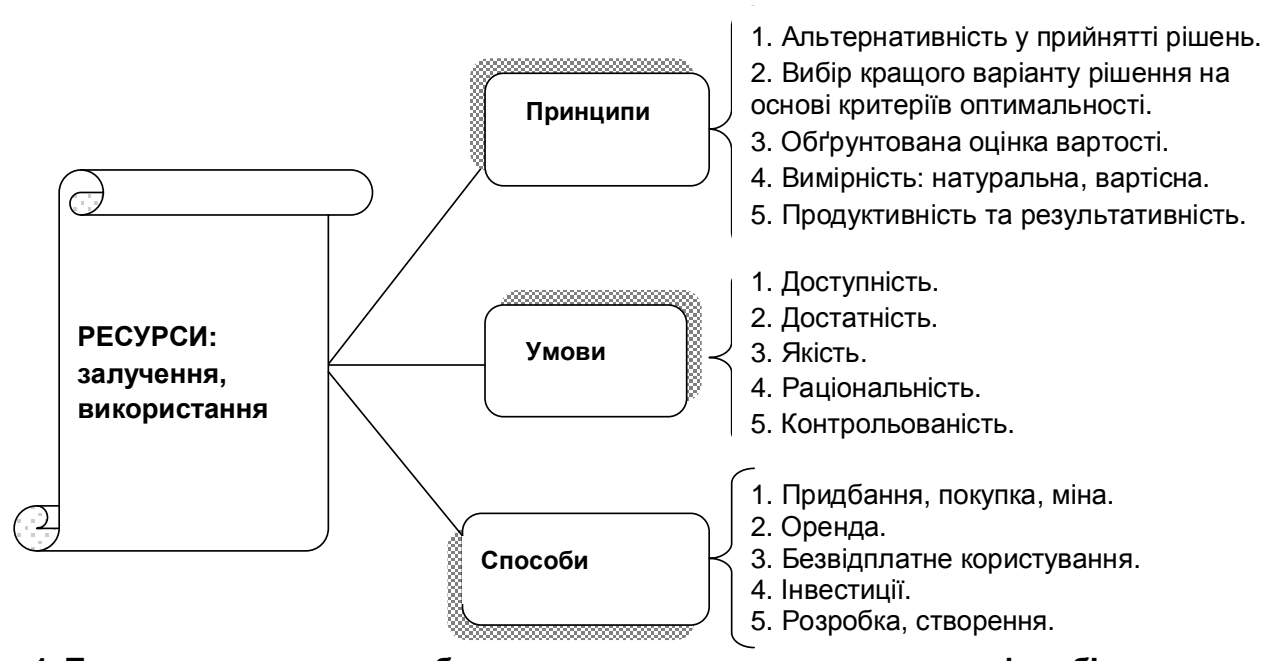

Рис. 1. Принципи, умови, способи залучення та використання ресурсів суб'єктом економіки.

Зазначені принципи, умови та способи залучення ресурсів повною мірою стосуються ресурсів такого суб'єкта економіки, яким є міська агломерація. Управління ресурсами міської агломерації полягає в цілеспрямованій дії на економічні відносини, що виникають у процесі формування, розподілу й використання ресурсів із метою досягнення цілей стійкого розвитку території й забезпечення високої якості життя населення в умовах зміни зовнішнього та внутрішнього середовища.

У табл. 1 представлено класифікацію загального складу ресурсів міської агломерації. Слід зазначити, що до такого складу можуть включатися інституційні умови, підприємницькі здібності; адаптаційні можливості територіальних громад, що входять до складу міської агломерації.
Методологічні основи управління ресурсами міської агломерації включають конкретизацію завдань відповідно до головної мети підвищення якості життя населення на основі стійкого розвитку території, узагальнення принципів та функцій управління. До функцій управління ресурсами міської агломерації відносять планування ресурсів, способи й методи вимірювання та оцінки ресурсів, контроль та аналіз результативності й ефрективності залучення та використання ресурсів, моніторинг зовнішнього середовища, яке впливає на ресурси, маркетинг ринків ресурсів.

Технологія управління ресурсами використовує сукупність методик, методів, прийомів, інструментів, а також визначення порядку й регламенту виконання обліково-аналітичних, інформаційних, організаційних і 
Таблиця 1. - Класифікація ресурсів міської агломерації

\begin{tabular}{|c|c|}
\hline Вид ресурсів & Як групуються \\
\hline Природні ресурси & За способом використання та за вичерпаністю \\
\hline Людські ресурси & Демографічні, поселенські, соціальні, трудові, \\
освітньо-кваліфікаційні (кадрові)
\end{tabular}

координаційних операцій щодо управління ресурсами міської агломерації.

Обґрунтування рішень щодо управління ресурсами міської агломерації здійснюється за допомогою таких методів, як бюджетування, програмування та проектування. Сутність бюджетування можна визначити як інтегровану систему складання бюджетів, поточного контролю за виконанням прийнятих бюджетів, обліку відхилень фактичних показників від бюджетних й аналізу причин істотних відхилень. Найбільш істотними є такі переваги бюджетування: виявлення резервів і джерел мобілізації ресурсів; забезпечення нормального кругообігу грошових коштів у рамках бюджетного періоду за всіма стадіями й сегментами діяльності; урахування інтересів інвесторів й інших учасників фінансового забезпечення діяльності; створення умов для виконання зобов'язань перед фінансовими організаціями, банками, державою; контроль і забезпечення фрінансової стійкості в довгостроковій перспективі.

Програмно-цільовий метод планування полягає у відборі пріоритетних цілей економічного, соціального, науково-технічного розвитку, розробці взаємопов'язаних заходів щодо їх досягнення в задані терміни з максимальною ефективністю при необхідному забезпеченні ресурсами. Метод включає розробку програм 3 урахуванням стратегічних цілей, визначення шляхів, засобів й організаційних заходів щодо їх досягнення, узгоджених за ресурсами, термінами й виконавцями.

Під системою управління проектами розуміється набір методів, ресурсів і процедур, що використовуються для прийняття відповідних проектних рішень. Система управління проектами об'єднує процеси й пов'язані з ними фуункції контролю в єдину цілеспрямовану структуру. Управління ресурсами $є$ розділом управління проектами, який відображає в собі тільки ті процеси, які достатні й необхідні для забезпечення цілей проекту за рахунок оптимального використання наявних ресурсів. Управління ресурсами проекту включає основні принципи планування ресурсів; управління закупівлями, постачанням та запасами; методи управління матеріально-технічним забезпеченням, логістику, процеси управління ресурсами проекту.

Як інструменти управління ресурсами міської агломерації доцільно використовувати процедури управління ресурсами соціально-економічного розвитку території та методики оцінки ресурсного потенціалу території $[4,8,9]$.

Процедура управління ресурсами соціально-економічного розвитку території здійснюється поетапно та включає моніторинг соціально-економічного розвитку території, аналіз напрямів руху ресурсів, закономірностей у ресурсних потоках, організаційних моделей управління міським господарством; формування матриць SWOT-аналізу для визначення стратегічних напрямів економічного розвитку території; виявлення законодавчих обмежень і можливостей управління ресурсами; виділення ключових ресурсів розвитку; обґрунтування та реалізацію прийнятих рішень, включаючи контроль їх виконання за термінами й джерелами ресурсного забезпечення.

Методика оцінки економічних ресурсів розвитку території передбачає розрахунок інтегрального показника ресурсозабезпеченості території з дотриманням принципів комплексності інтегральної оцінки розвитку сукупних економічних ресурсів території; порівняльного аналізу з динамікою розвитку економічного потенціалу іншої території; структурного аналізу економічних ресурсів розвитку території; виявлення проблемних (нерозвинених) потенціалів у структурі економічного потенціалу території.

При прийнятті рішень щодо управління ресурсами необхідно також оцінювати ступінь раціональності їх використання. Оцінку раціональності використання ресурсів можливо проводити різними способами, але з дотриманням таких основних методологічних принципів:

- орієнтації кожної стадії процесу розвитку на комплексне використання всієї сукупності ресурсів з урахуванням перспектив їх розвитку в цілому;

- націленості системи ресурсів на активне впровадження новітньої техніки й технологій, підготовку кадрів різних спеціальностей і професій для формування високоінтелектуальних ресурсів.

Склад показників раціональності використання ресурсів визначається цілями, суб'єктами аналізу, доступністю та достовірністю інформації.

Указані методи та інструменти включаються до інформаційної системи ресурсного забезпечення міської агломерації, яка є сукупністю інформаційних процесів для задоволення потреб усіх зацікавлених користувачів в інформації різних управлінських рівнів або центрів ухвалення рішень. Це дозволяє підвищити обґрунтованість програмних документів та визначити необхідне ресурсне забезпечення щодо координації стратегій соціально-економічного розвитку території, оптимізації житлової забудови, формування рекреаційних зон та транспортно-логістичних центрів, модернізацію інфраструктури та міського середовища міської агломерації.

\section{Висновки}

1. Міські агломерації відіграють важливу роль у структурі національної економіки України й мають особливості, пов'язані з необхідністю організації співпраці територіальних громад, що входять до агломерації, на основі об'єднання зусиль і спільного використання ресурсів.

2. Ресурси міської агломерації мають характерні риси, пов'язані з властивостями й можливостями задоволення потреб, принципами, умовами, способами й вартістю залучення ресурсів. Управління ресурсами включає формування, розподіл і раціональне використання на основі ухвалення відповідних рішень.

3. До методів управління ресурсами міської агломерації відносяться: бюджетування, програмування, проектний аналіз. Як інструменти управління ресурсами доцільно використовувати процедуру управління 
ресурсами соціально-економічного розвитку території й методику оцінки ресурсного потенціалу території. При обґрунтуванні рішень щодо управління ресурсами також необхідно оцінити раціональність їх використання.

4. Принципи, методи, інструменти управління ресурсами утворюють модель ресурсного забезпечення, яка включається до інформаційної системи підтримки прийняття рішень з управління міською агломерацією.

Подальших досліджень вимагають питання підвищення раціональності використання ресурсів міською агломерацією з урахуванням забезпечення необхідного рівня результативності й ефективності інвестиційних проектів їх розвитку.

\section{ЛITЕРАТУРА}

1. Територіальний розвиток в Україні: розвиток агломерацій та субрегіонів / Агентство США з міжнародного розвитку (USAID) в рамках Проекту "Локальні інвестиції та національна конкурентоспроможність" (USAID ЛIHК). - К., 2012. -132 c.

2. Михуринская Е. А. Городские агломерации как форма развития урбанизированных территорий / Е. А. Михуринская, Р. А. Мартиросова // Экономика и управление. - 2011. № 4. - С. 114-118.

3. Сиройч Здислав. Эволюционное развитие городских агломерацій / Здислав Сиройч. - К. : Объединенный ин-т экономики НАН Украины, 2005. - 209 с.

4. Биченко Л. А. Управління соціально-економічним роз- витком міських агломерацій / Б. А. Биченко // Економіка та держава. - 2011. - № 3. - С. 92-93.

5. Fujita M. Economics of agglomeration: cities, industria location, and regional growth / Masahisa Fujita, Jacques-Francois Thisse. - Cambridge, JK ; New York : Cambridge University Press, 2002. - 466 p.

6. Glaeser E. The Wealth of Cities: Agglomeration Economies and Spatial Equilibrium in the United States [Електронний ресурс] / E. Glaeser, J. Gottlieb. - Режим доступу : http://scholar. haivard.edu/glaeser/publications.

7. Phelps N. Contrasts in agglomeration: proto-industrial, industrial and post-industrial forms compared / N. Phelps, T. Ozawa // Progress in Human Geography. - 2003. - № 27 (5). - Pp. 583-604.

8. Трунова Н. А. Совершенствование методических подходов к анализу и оценке факторов, влияющих на развитие городских агломераций / Н. А. Трунова // Экономика и управление. - 2011. - № 3 (76). - С. 205-208.

9. Тищенко О. П. Ресурсний потенціал міських агломерацій: проблеми ефективного управління / О. П. Тищенко, Н. В. Присяжнюк // Економічний часопис-XXI. - 2013. - № 9/10 (2). - C. 3-6.

10. Евдокимова Л. О. Концепции развития ресурсного потенциала субъектов экономики: сравнительный анализ, методологические решения [Електронний ресурс] / Л. О. Евдокимова // Общество. Среда. Развитие. - 2012. - № 3. - Режим доступу : http://cyberleninka.ru/article/n/kontseptsii-razvitiya -resursnogo-potentsiala-subektov-ekonomiki-sravnitelnyy-analizmetodologicheskie-resheniya.

Мельникова Марина, доктор экономических наук, доцент, ведущий научный сотрудник отдела экономико-правовых проблем градоведения Института экономико-правовых исследований НАН Украины

\section{УПРАВЛЕНИЕ РЕСУРСАМИ ГОРОДСКИХ АГЛОМЕРАЦИЙ: ПРИНЦИПЫ, МЕТОДЫ, ИНСТРУМЕНТЫ}

В статье рассмотрены проблемы управления ресурсами в процессе развития городских агломераций. Определены особенности городской агломерации, среди которых необходимость объединения усилий территориальных громад, которые входят в состав агломерации, на основе управления их ресурсами. Выявлены характерные черты ресурсов, включая свойства, возможности удовлетворения потребностей, принципы, условия, способы и стоимость привлечения. Представлены методы и инструменты управления ресурсами городской агломерации. Принципы, методы, инструменты управления ресурсами предложено включать в информационную систему поддержки принятия решений по управлению городской агломерацией.

Ключевые слова: городская агломерация; ресурсы; управление; методы и инструменты управления ресурсами.

Melnikova Marina,

Doctor of Economic Science, Associate Professor,

Leading Researcher of Department of Economic and Legal Problems of City-study

of the Institute of Economic and Legal Research of NAS of Ukraine

\section{RESOURCE M ANAGEMENT URBAN AGGLOMERATIONS: PRINCIPLES, METHODS, TOOLS}

In article the problem of resource management of urban agglomerations were considered. The role of urban agglomerations in the structure of the national economy of Ukraine was characterized. Features urban agglomerations were identified. These features include the need for cooperation of territorial communities that are part of the urban agglomeration. Cooperation is carried out in the following areas: the development of urban infrastructure, the creation of logistics centers, coordination of urban land use, environmental protection. For projects of cooperation requires resources. Resources urban agglomerations is divided into: natural, human, economic, organizational and legal. Features resources of urban agglomerations were identified. These include: properties, the ability to meet the needs, principles, conditions, ways to attract, determination of the price. Resource management involves the formation, distribution and rational use of resources. The aim, methodology, technology resource management conurbation were identified. Methods of resource management urban agglomerations include: budgeting, programming and project analysis. Were presented resource management 
tools urban agglomeration: the stages of resource management of socio-economic development; method of estimating the resource potential of the territory. When making decisions on resource management assessed the rationality of their use. The information system includes principles methods, tools, resource management urban agglomerations. This allows you to improve the validity and efficiency of decision-making on management of urban agglomerations.

Keywords: urban agglomeration; resources; management; methods and tools of resource management.

\section{REFERENCES}

1. Territorial Development in Ukraine: development of agglomerations and subregions (2012), U.S. Agency for International Development SAID) under the "Local Investment and National Competitiveness", Kyiv, 132 p. (ukr).

2. Mikhurinskaya Ye. A., Martirosova R. A. (2011), Urban agglomerations as a form of development of the urbanized territories, Economics and management, 4, pp. 114-118 (rus).

3. Siroych Z. (2005), Evolutionary development of urban agglomerations, United Institute of Industrial Economics of NAS of Ukraine, Kiev, 209 p. (rus).

4. Bychenko L. A. (2011), Management of social and economic development of urban agglomerations, Economics and state, 3 , pp. 92-93 (ukr).

5. Fujita M., \& Thisse J.-F. (2002), Economics of agglomeration: cities, industrial location, and regional growth, Cambridge, UK, New York, Cambridge Jniversity Press, 466 p. (engl).

6. Glaeser E. (2009), The Wealth of Cities: Agglomeration Economies and Spatial Equilibrium in the United States, available at: http:/ /scholar.har- /ard.edu/glaeser/publications/ (engl).

7. Phelps N., Ozawa T. (2003), Contrasts in agglomeration: proto-industrial, industrial and post-industrial forms compared, Progress in Human Geography, 27(5), pp. 583-604 (engl).

8. Trunova N. A. (2011), Improvement of methodological approaches to the analysis and evaluation of factors affecting the development of urban agglomerations, Economics and management, 3(76), pp. 205-208 (rus).

9. Tyshchenko O. P., Prysiazhniuk N. V. (2013), Resource potential of urban agglomerations: problems of effective management Ekonomichnyi chasopys-XXI, 9/10 (2), pp. 3-6 (ukr).

10. Yevdokimova L. O. (2012), Concept of development of the resource potential of agents economy: comparative analysis, methodological solutions, Society. Environment. Development, 3, available at: http://cyberleninka.ru/article/n/kontseptsii-razvitiyaresursnogo-potentsiala-subektov-ekonomiki-sravnitelnyy-analiz-metodologicheskie-resheniya (rus).

(C) Мельникова Марина

Надійшла до редакції 30.04.2015

УДК 331.104

ПАНЬКОВА АННА,

аспірант Інституту економіки промисловості НАН України

\section{ПРАВОВІ ЗАСАДИ РОЗВИТКУ ТРУДОВИХ ВІДНОСИН У КОНТЕКСТІ СОЦІАЛЬНОЇ ВІДПОВІДАЛЬНОСТІ}

У статті визначено та проаналізовано основні правові засади, на яких ґрунтується трудова сфера. Визначені проблеми та перешкоди щодо формування правових засад розвитку трудових відносин та трудової сфери України в контексті соціальної відповідальності та обґрунтовані напрями щодо становлення та впровадження таких засад.

Ключові слова: праця; законодавство; трудова сфрера; соціальна відповідальність; працівник; роботодавець; держава.

Актуальність та постановка проблеми. Здобуття не залежності України супроводжувалось прагненням держави до формування нової правової бази, до певного змагання $з$ іншими країнами пострадянського простору щодо прийняття законів у сфері праці. Україна була лідером у прийнятті Закону України "Про охорону праці" (1992 рік) [3] і за терміном, і за змістом, бо закон передбачав фінансову підставу його реалізації завдяки багаторівневій системі фондів охорони праці, запровадженню середньострокової системи планування умов та охорони праці, а також делегування функцій управління охороною праці від профспілок державі. Україна стала на передові позиції за змістом та терміном прийняття у 2013 р. Законів України "Про зайнятість населення" [5], "Про колективні договори та угоди" [4] Низка наступних законів, які визначили правові засади розвитку та управління трудовою сферою, уже була закономірним кроком змістовного наповнення трудового законодавства, яке регламентувало базові норми права щодо оплати праці, відпусток, колективних трудових спорів (конфліктів), соціального діалогу тощо. Високою була ініціатива щодо розвитку трудового за- 